Canadian University Music Review

Canadian University Music Review

Revue de musique des universités canadiennes

\title{
"How Can You Dance to Beethoven?": Native People and Country Music
}

\section{Lynn Whidden}

Numéro 5, 1984

URI : https://id.erudit.org/iderudit/1013932ar

DOI : https://doi.org/10.7202/1013932ar

Aller au sommaire du numéro

Éditeur(s)

Canadian University Music Society / Société de musique des universités canadiennes

ISSN

0710-0353 (imprimé)

2291-2436 (numérique)

Découvrir la revue

Citer cet article

Whidden, L. (1984). "How Can You Dance to Beethoven?": Native People and

Country Music. Canadian University Music Review / Revue de musique des

universités canadiennes, (5), 87-103. https://doi.org/10.7202/1013932ar

All Rights Reserved (C Canadian University Music Society / Société de musique des universités canadiennes, 1984
Ce document est protégé par la loi sur le droit d'auteur. L'utilisation des services d'Érudit (y compris la reproduction) est assujettie à sa politique d'utilisation que vous pouvez consulter en ligne.

https://apropos.erudit.org/fr/usagers/politique-dutilisation/ 


\title{
"HOW CAN YOU DANCE TO BEETHOVEN?"*: NATIVE PEOPLE AND COUNTRY MUSIC
}

\author{
Lynn Whidden
}

A native scholar once asked me: "Why is country music, with its sad themes of broken homes and hearts, so popular among native people?" Of course country music is popular among many non-natives too, but its overwhelming pervasiveness in native society deserves investigation. Surely such a strong musical predilection can provide considerable insight into the native ethos.

For the purpose of this discussion the term "country music" will be broadly defined to include commercial country music and its progeny, country music with a western flavor or countrywestern, and country music with a rock rhythm or country-rock. Because it generally comes from different sources and has had a different historical development, fiddle music is not discussed in this paper, although it is definitely considered as country music by native people. The music genre categories employed in Tables I-III are those used in a popular record shop in Thompson, Manitoba, which tries to make recordings by native musicians available to the public. These genre categories, I believed, would be understood by my subjects.

To test the assumption that country music is commonly liked among the native people of Manitoba, I observed, for a two-year period (1980-82), the musical preferences of several groups of natives, mainly Cree and Sioux, from both rural and urban areas. First, a popular native radio show, planned and executed exclusively by native personnel, was monitored. Besides the regular music programming the announcer gives, in English and in Cree, upcoming community events, the condi-

*Response of a native person when asked why she liked country music.

Canadian University Music Review, No. 5, 1984 
tion of hospitalized persons, messages to persons on the traplines, and numerous advertisements from local businesses translated into Cree, the most notable being the jingle for Kentucky Fried Chicken. Table I categorizes the total number of songs played during five successive weeknights, 8 p.m.-9 p.m., on the Native Communications show, radio CHTM in Thompson:

\section{Music Genre}

Country (e.g., Don William's

"I Believe in You")

Rock and roll (e.g., Bonnie Tyler's

"It's a Heartache")

Traditional native

Popular (e.g., Anne Murray's

"You Needed Me")

\section{Number of Songs}

60

1

1

Table I

Table II shows the response of twenty native university students who were asked to list their favorite music. Although this sample is hardly representative of northern native communities in general, it nonetheless provides an initial insight into the differences in patterns of musical taste between native and nonnative peoples:

\section{Number of Persons}

11

4

3

1

1
Music Preferences

Country

Rock and roll

Powwow

Popular

Folk

(In this group five of the twenty respondents listed country music as their second choice.) 
Contrast these musical preferences with those of thirteen nonnative university students:

Number of Persons

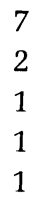

Music Preferences

\author{
Popular \\ Classical \\ Gospel \\ Bluegrass \\ Jazz
}

Table III

The impression I had gained over ten years of listening to native broadcasts was confirmed by the number of country songs played and by the number of natives who prefer country music. Certainly country music is a favorite with the young adult native population, and I believe that the count might be even more strongly in favor of country music with the older generation.

The dedications on the radio show deserve special mention. One native announcer explained the reasons for and the patterning of the requests in this way:

These types of programs are called dedications. Through these dedications, people choose their own songs to express their feelings for the person they are sending the song to. Most of these chosen songs are country and western type songs. Some of them choose a song to tease another person; for example, the girls send a song like "You Ain't Woman Enough To Take My Man." Another song they choose is "Take Me Back and Try Me One More Time." These songs are selfexplanatory. The receiver understands the message. The person might reply with a song like "I Will" (Personal communication, July 1982).

The use of overt messages in country music was affirmed in a statement made to me by a young woman: "To this day native men are very non-verbal in romantic situations. The expressions of love between men and women in country music has given native people a means of expressing these kinds of emotions" (Personal communication, August 1982).

This statement can be confirmed in the light of what is generally thought to be Cree personality. According to John Bennett: 
... some of the values of the Indian male were shared with those of the rancher. Masculinity, taciturness [sic], individualism-these are all values which find an echo in the old Plains Cree social organization. The Indians were aware of their similiarity and so found it possible to identify with the ranching and riding culture... (1971: 114).

Bennett's assessment of Plains Cree personality applies generally to the northern Cree with whom I worked. They are a quiet, contained people; individual desires are respected, as are the males who head the household. Undoubtedly these personality traits facilitate acceptance of country music and particularly of country-western and cowboy songs which stress these traits.

There are historical factors that explain the past and present popularity of country music. During the eighteenth and nineteenth centuries the natives were exposed to the vigorous prosyletizing efforts of the Christian missionaries and simultaneously to the music of the white man-Christian hymnody as well as the songs, dances, and instrumental music of the explorers, trappers, and traders. Until 1763 the Hudson's Bay Company was the sole trading company active in northern Manitoba and trading posts were established only along the coast. But by 1821 both the Hudson's Bay Company and the Northwest Company were competing for trade and there were numerous inland posts. By 1900 both the trader and the church were significant influences in the life of northern Manitoba natives. In 1907 a rectory was built at Pukatawagan and staffed with the first Roman Catholic priest to take up permanent residence in northern Manitoba. And in 1910 the Vicarate of Keewatin was established with a bishop in The Pas. Here is a characteristic opinion of native religion by an early missionary:

Their superstitious fears (called their religions) influence their impressible and fickle spirits in a manner that at times is almost incredible, and cause them to inflict sufferings upon themselves as severe as any inflicted by the devotees in the worst regions of India or Africa. The religion of the Red Indians is mixed up with all they see or hear or do (Young 1893: 80).

Certainly religion and music were "mixed up" and with the massive conversions to Christianity, traditional native hunting songs quickly disappeared. In addition, the traditional song differed so drastically from Christian hymnody that there was 
little possibility of a syncretic music developing. Rather than acquiring overt characteristics of traditional song, Manitoba native gospel songs and hymns acquired a country music flavor, particularly with regard to rhythm, vocal timbre, and the use of guitars.

And it is no wonder that country music became the music of the people, for, as several informants emphasized to me, they were raised with it:

I remember my mother used to get up early every morning to do her chores to the sound of country music which was on from five to seven every day except Saturday and Sunday. This morning ritual continued for quite a few years. I must have been pre-school age, when I first remember listening to the radio, until I was about ten or eleven years old when our radio broke down (Personal communication, July 1982).

Since the 1930s natives have had radios in the isolated settlements. The early radios, often referred to as radio cabinets, were large, ran on dry cell batteries the size of today's car batteries, and required a ground wire and high aerial wire. In the evenings, the best and sometimes only radio reception was from the American midwest-country music shows from Del Rio, Texas, Waterloo, Iowa, and Omaha, Nebraska. Hank Williams, Jimmie Rodgers, and Kitty Wells became community favorites as people gathered around their radios, not only to enjoy the music passively, but to learn the words and tunes of the songs. Later, local radio stations, CKDM from Dauphin, Manitoba, for example, developed shows combining country music with news and messages from family and friends at home to those on the traplines. Thus acculturation provides strong reason for the overwhelming popularity of country music in the North.

Country music is, moreover, congruous with life in the native settlements. The musical instrument most often associated with country music, the guitar, is relatively easy to store, maintain, and carry about. It is also inexpensive and available to rural persons through catalogue sales. Not only did the native have access to store-bought guitars, he could also fashion his own stringed instruments from materials at hand. Charlie Panigoniak, an Inuk from Eskimo Point, Northwest Territories, sketched his first tin-can guitar for me in this way: 


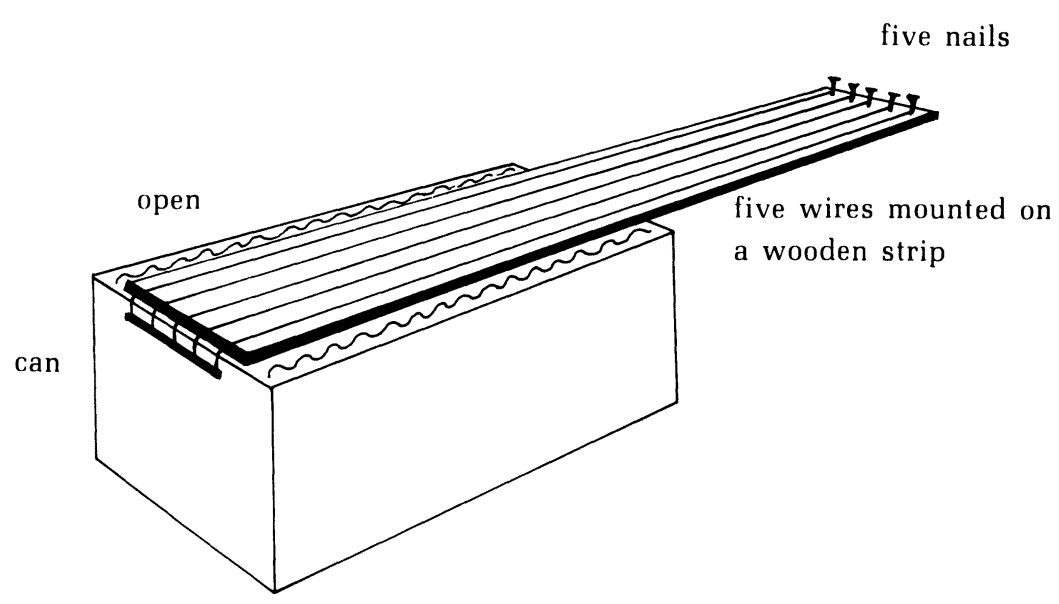

People in remote communities had to provide their own entertainment. Frequently an impromptu dance would be called at someone's home. As word of the evening's entertainment spread around the community, the family would busy itself stacking all the furniture in a corner of the house, or even outside. Several of the adult males in each family could play the fiddle and guitar for the dance, and they would all have a turn playing, since the music would go on continuously throughout the night. Here is a firsthand description of such a dance:

These dances went on for twenty-four hours. One group of dancers would dance for a few hours then another group would arrive, allowing the first group to go home and sleep for a few hours. The nearest next-door neighbor would supply the food and tea to all the people. People from the two closest reserves would arrive to join in these dances. The music could be heard clear across the whole reserve on these cold winter nights (Personal communication, August 1982).

Country music is easily assimilated by ear. The melodic lines are simple and direct and it is necessary to know only a few chords in order to play an acceptable guitar accompaniment. Moreover, most northern Cree remain aural in orientation and quickly learn to play and sing by ear. One woman described how her aunt learned to play the guitar:

Learning how to play was done mostly by ear. She said she would sing one tune or note and play the chords that she thought were appropriate for the song. If they sounded like 
the right notes to her she would keep that in her mind and go on to another chord. Most of the ones that she knew were the chords that she had learned by watching other people play guitar (Personal communication, August 1982).

Thus the ready availability of country music combined with the simultaneous loss of native musical traditions is an important factor in the popularity of country music. But let us return to the young adults mentioned in Tables II and III and their reasons for liking country music. Included here are a few representative quotations from the fifty-one informants. Those who preferred country music stressed the words to the songs, describing them as clear and comprehensible. To them, country songs tell stories about common everyday people, stories to which they can relate-true-to-life stories:

- "Country music is easily understood; you can hear each word."

- "I find their lyrics simple and definitely not complicated to understand. They seem to reveal their messages right out in the open."

- "Another reason is that it tells a story, a story of ordinary people."

- "I enjoy country and western music because I could relate to the singer's feelings. For whenever I listen to their songs it seems they are always trying to send their messages across to the audiences."

They told of liking the music because it is slow, has an even tempo, and flows smoothly. They described the sound as soft, quiet, and mellow, with no high notes. Several persons mentioned that country music is often sung solo, that it is simple music:

- "Country music is my favorite because it is quiet and relaxing. The songs have meaning and you are able to understand what you are listening to."

- "I find this type of music most enjoyable because I find that it makes me relax, and it also makes me comfortable."

- "I also like it because of the rhythm. It is relaxing and it usually soothes my feelings."

Many social factors were given as the cause for the popularity of country music. The songs appeal to all age groups, to rich and poor alike. They can be sung anywhere; there is no formality involved. They are not protest songs but songs for relaxation 
and entertainment. Country music can be found everywhere and is heard each day on the radio:

- "In country music there is no formality involved."

- "Country music is widely heard each day on the radio."

- "I enjoy listening to this because everyone likes it."

The informants' adjectives-"easy to understand," "easy listening," "relaxing and not formal"-seem to embody the main reasons why the natives interviewed like country music. One of my native friends put it this way:

I guess a shoe analogy would be quite accurate-one can have a number of different styles, colors, and types of shoes for various occasions, but there is usually one pair that you slip into when you want to be comfortable. That's how country music is with me (Personal communication, 1980).

Thus we have the insider's reasons for the popularity of country music. Certainly it is true to say that country music fits the native world view and aesthetic system or we would not have such conclusive evidence for its popularity. But by approaching the question from another angle we may further elucidate why country music fits so well the native world view.

It is common knowledge that natives view themselves as one with nature. Their lives were directly interdependent with those of animals and even plants. The extent of this interdependency is revealed in native stories of shapeshifting-for example, the trickster is sometimes man, sometimes beast. A corollary to this view is the attitude that man must propitiate and work with nature, but that nature cannot be controlled except by special individuals, such as medicine men, and then only in special circumstances. Traditionally, there was no buffer between the elemental forces and man; consequently human beings had to subordinate themselves to, and accept the dictates of, nature. With this submission to fate, real tragedy is possible in the native world view. Contrast this to the North American non-native world view, which, until recently at least, has operated on the assumption that nature can be changed and controlled for the use of mankind, and that the human is superior to, and apart from, the remainder of nature. The western world view is unfailingly optimistic, and our popular expressions reflect this faith in the cliché, for example, of the happy ending.

I believe that this acceptance of tragedy, the realization that some situations are hopeless, continues to be part of the 
native world view and undoubtedly serves to explain in part the continuing popularity of country songs and their stories of utter despair, stories that seem maudlin and even ridiculous to the non-native, with his progressive world view:

When I looked out my window and I saw that same little boy kneeling by a grave in an old cemetery,

Well I stopped my car and walked over to where the little boy was kneeling down,

And he smiled up at me and said, "This is where my mama stays and she says she sure does thank you for these pretty roses."

In her book, Native American Music, Marcia Herndon writes: "Therefore the relationship of Nature to society causes the Native American to create art which is oriented toward the intuitive and the emotional" (1980: 73). She explains that natives believe nature reveals her dictates to people through dreams, visions, intuition, and transcendental experiences, that the native emphasizes phenomenal knowledge as opposed to the non-native emphasis on noumenal knowledge. Certainly country music appeals directly to the emotions, and the words and music are easily accessible to the native, as was evident in the above quotations. The themes have direct and immediate appeal-themes of family life, love, loneliness, and death. As one native said: "Country music represents solid reality to me" (Personal communication, July 1982). To the native, country music is a feeling, not an attempt to create intricate musical structures or messages which are not self-evident. One young woman outlined a series of traumatic events in her life -alcoholism, beating, attempted suicide, divorce-and described how certain country songs applied directly to her feelings at each event:

I enjoy the songs so much because so many of the words fit the way I've lived and felt throughout my life. I get stuck trying to put into words how I felt during a certain stage of my life and then a song echoes from a radio, television, record or tape saying precisely what it is I'm trying to express (Personal communication, August 1981).

Domination by white society further strengthens the native belief that mainstream twentieth-century society operates under forces beyond his control. This contrasts with the dominant nonnative view that man is in control, that through the scientific method everything can be explained and therefore controlled. Words of resignation are common: 
So when you've had your fun

And you still need someone,

Come on home to the arms of a fool.

The words "city lights" in juxtaposition with "country girl (boy)" have become commonplaces favored by native singers. Certainly these images have direct appeal to the majority of Manitoba Cree, who are primarily rural people. Many of those who flock to the cities-Winnipeg, for example-find themselves unable to cope in non-native society. Even those who venture to town for only a weekend frequently get involved in unpleasant incidents.

Don't you know these city lights can really blind a country girl,

People offer things she's too green to refuse,

But there's nothin' worse than neon

When the morning sun shines through,

To a hillbilly girl with the blues.

Indeed, one might speculate that these songs are symbolic of the more general discomfiture that natives feel in their relations with white society. Unlike the white emphasis on printoriented visual perception, with its concomitant emphasis on the linear and the idea of progress, the native has stressed aural learning and a conception of time as a cyclical rather than a linear progression. For example, according to Barre Toelken:

The Navajo concept of time is most similar to European concepts of space; insofar as the Navajos talk about anything like time at all, it is not seen as a pathway along which one moves but a context in which things come to pass (1979: 237).

Much of traditional Cree music has a timeless quality. The music consists of repetitive patterns that give it a circular quality as the music passes through time. Rather than follow the progressive Euro-American narrative curve (see Childs 1977: 195) the melodic and rhythmic elements of native songs may be terminated at any juncture.

Likewise in their renditions of country music, native performers frequently exhibit a similar lack of concern with beginning at a regularly specified time, such as after a two- or four-bar introduction. Furthermore, it is often difficult to sing along with native performers of country music, for their music does not always progress in precise measures and phrases. The number of beats or pulses per measure may vary freely even in songs that are copied from recordings. There are several possible expla- 
nations for the metrical flexibility, including the freedom of the solo performer, but it is also possible that the lack of musical precision acceptable in country music performance reflects a lack of concern for progressive, linear time. Considering the strong meters of commercial country music heard by the Cree, their apparent willingness to manipulate meter in their own renditions is striking and, I believe, reflective of a different approach to the use of time.

Besides the flexible internal structuring to the meter, the contexts in which country music is played and heard are frequently unstructured and informal, definitely accomodating "Indian time" - a cliché used frequently but ill-advisedly to indicate tardiness. Susan Philips has provided a perceptive interpretation of Indian time as she observed it on the Warm Springs Reservation in central Oregon. She noticed the perplexity of non-natives attending native events on the reservation. The starting time of the event is not clear, nor is the progression of events to follow. Her description of events run on Indian time is reminiscent of many social situations I have observed in which country music prevails. A favorite activity of many northern natives who come to an urban area for the weekend is participating in the activities of a tavern. To the non-native observer the movement of individuals in and out of the tavern, the continuous motion, is striking. There is no commitment among individuals to be at the tavern at a certain time or to remain there for a pre-determined period of time. Everyone is welcome and not criticized if he or she fails to show up or chooses to leave early. This loose structuring of the tavern appears to be congenial to the native population who value selfdetermination and individual freedom in inter-personal interaction:

... the Warm Springs Indians have repeatedly made organizational choices that maximize the possibility that everyone who wants to participate is given the chance when he or she chooses to and in the way he or she chooses to (Philips 1974: 107).

While this freedom of participation is basic to attendance at a tavern it does not extend to the group of country musicians, who are frequently native. Certain of these performing groups are prone to operate on Indian time, much to the chagrin of the tavern manager.

This brief analysis of the tavern setting for country music supports the statements of the young natives interviewed who 
stressed that their enjoyment of country music was a result of the informality associated with the music. Undoubtedly the absence of rigorous time boundaries enhances the appeal associated with most country music events.

There is another area of similarity between country music and traditional native music, again related to the Cree tendency to eliminate markers, in this case, to clearly differentiate speech from music. This technique, labelled "diseuse" by linguists, is defined by Charles Boilès as the process of:

... becoming reciters of the lyrics. They abandon the singing mode of producing fundamental frequencies in a fixed sequence; they adopt the reciting mode which uses indiscriminate selection of the fundamentals and durations with a set pattern of phonation (1977: 551).

In traditional Cree song, narrative is interspersed with song in such a fluid, unified fashion that the boundaries of each vocal genre largely disappear or at least are well obscured. Moreover, as Boilès points out, the diseuse technique occurs in country music. To illustrate, I cite a song called "Streets of Winnipeg" (sung to the tune of "Streets of Laredo") and performed in country style with guitar accompaniment. The changes from sung to spoken vocalization are indicated. Besides the alternation of spoken and sung words,"Streets of Winnipeg" holds interest since its words of protest are exceptional in songs sung in country music style:

\section{"Streets of Winnipeg"}

Sung:

Hey, ho

Way ya ho hey ho

Way ya ho ho-a-ho ha ho

As I walked down

The streets of Winnipeg one day,

As I walked down

The streets of Winnipeg one day,

I spied a young Indian wrapped in white linen,

All wrapped in white linen

And cold as the clay. 
Spoken:

He staggered down the sidewalk

In his unkempt clothes with his shoulders stooped

And his head bowed low

And his eyes that stare in defeat,

With his three-day-old whiskers

And his body that smelled full of wine odor

Thinking to himself,

Who am I? Who am I?

What am I?

You come to the big city

Because somebody said that life would be easier

Regardless of race, color, or creed

Regardless of race, color, or creed, huh,

That's a laugh

Because in the big city

He can be accepted of his own kind

And all he could do is drink, drink, and drink.

And searching within himself the things of life

There are things that he could not understand,

Why back home, why nobody dies of old age anymore,

I remember when I was a child

And I believe in those things that I was taught.

The first thing that I was taught to sing

Was O Canada,

And if I had to sing those words again

I would sing them this way:

O Canada, our home and native land,

The true north is not strong and free anymore,

True patriot love our hearts command

That thee may rise $O$ Canada

Our used-to-be home and native land,

And now things are different,

It is no longer our native land,

For the government's greed has overtaken them

And now, such is the way of life.

As he walks down the street

He comes to a red light,

He looks up at the red light and says,

Red light, they call me red man too,

Maybe they mean for me to stop,

Waiting for the green light

Is like waiting for the green grass, the green trees 
The green leaves, the pure waters,

Yeah but, the government's greed

Has overtaken them,

And such is the way of life

And ignoring the oncoming traffic

He steps out into the street.

Sung:

As I walked down

The streets of Winnipeg one day,

As I walked down

The streets of Winnipeg one day,

I spied a young Indian wrapped in white linen,

All wrapped in white linen

And cold as the clay.

Sing the song slowly, hey, hey hi ho

Hi ho hi ho hey hey

Beat the drum slowly,

I am a young Indian,

I am a young Indian

And I don't want to die.

In the face of seemingly insurmountable social and personal problems, it is not surprising that country songs do not encourage direct action but rather offer solace and comfort. The native's outwardly passive and intuitive solution to problem-solving contrasts with the rational direct attack of the Euro-American. Country music's appeal may lie in the fact that it is not protest music. Indeed, one native informant described it to me as "music to drink by." Despite the grave social problems of the native people, rarely has country music been used as a vehicle for group protest. The function of traditional native music may have been assumed by country music-that is, it has become a vehicle for preserving, not protesting, a particular life-style. As in most oral, non-literate societies, innovation as such is not prized; rather, music is useful for explaining, transmitting, and perpetuating the culture and the society. Indeed, the very conservative nature of country music may have strengthened, and may continue to strengthen, its acceptability to the native. As DiMaggio, Peterson, and Esco have noted: ". . . country music not only depicts the promise-and- 
denial tragedy, it also provides several means of rationalizing failure short of questioning the American dream itself" (1972: 51).

Not content with being mere consumers of country music, today the native Manitoba performers of country music are many: Leonard Constant from The Pas; the $\mathrm{C}$ Weed Band from southern Manitoba; Ernest Monias from Cross Lake; Len Henry of Boggy Creek, and many others. Most communities have amateur or talent shows where native entertainers compete for cash prizes. Although the musicians may pattern themselves after the likes of Waylon Jennings and Loretta Lynn, they all remain uniquely Cree in their concepts of musical time and performance context.

After recent successes of native country musicians such as Ray St. Germaine and Ernest Monias, there is tremendous enthusiasm among young people to become country music performers. Unfortunately the expense of travelling a least 650 kilometers south to the nearest recording studios in Winnipeg is prohibitive. But a few have done it, and their recordings are extremely popular among the northern natives. Again there is a problem with the distribution of the recordings, and even though local businesses may want to sell the product, it is often difficult to obtain. At the moment there is considerable speculation concerning the feasibility of establishing local recording studios.

An increasing number of songs are being written about life in the remote settlements, using names of local people and places. English remains the language of these country songs, in contrast to folk-style songs, which often attempt to use the Cree language. Following is the text of a song about northern life. The lyrics, by Jack Brightnose, bring a smile to those who know the north. Northerners understand the loneliness of life on the trapline, and all know the song "Forever is a Long Long Time," composed and sung by a popular native musician, Ernest Monias:

\section{"Traplines Blues"}

Here I am alone again

Out on my trapline,

Ever since I left my baby

Back in Pikwitonei,

Oh Lord I got it,

I got these trapline blues. 
Chorus:

I got these trapline blues,

Lord I got it bad

Ever since I left my baby

Back in Pikwitonei,

Oh Lord I got it,

I got these trapline blues.

I've been oh so lonesome here

Tryin' to shake these blues,

I've been skinnin' beaver

Lynx and muskrat too,

But Lord I got it,

I got these trapline blues.

Sittin' by myself

Listenin' to the radio play

Ernest Monias singin'

"Forever Is a Long Long Time,"

That's how it feels like

Alone with these trapline blues.

This paper has sketched only a few of the possible reasons for country music's popularity with native people. There are, to be sure, many other questions to be answered: Are there other musical similarities between traditional native musics and country music which help to explain its ready acceptance? While it is clear that the Christian clergy condemned traditional drumming and singing, what has been their attitude toward country music? Does country music help give native people a sense of community as their traditional music once did? 


\section{REFERENCES}

BENNETT, J.W.

1971: "A Cree Indian Reserve", in Elliott, J.L., ed., Native Peoples. BOILĖS, C. Scarborough, Ontario: Prentice-Hall, pp. 99-115.

1977: "Canto," in Enciclopedia, Giulio Einaudi, ed. Torino: CHILDS, B. Einaudi, 1977, II, 548-71.

1977: "Time and Music: A Composer's View," Perspectives of New Music, XX/2, 194-219.

DIMAGGIO, P., PETERSON, R.A., AND ESCO, J.

1972: "Country Music: Ballad of the Silent Majority," in Denisoff, R.S. and Peterson, R.A., eds., The Sounds of Social Change. New York: Rand McNally, 33-55.

HERNDON, MARCIA

1980: Native American Music. Norwood, P.: Norwood Editions. PHILIPS, S.U.

1974: "Warm Springs 'Indian Time': How the Regulation of Participation Affects the Progression of Events," in Bauman, R. and Sherzer, J., eds., Explorations in the Ethnography of Speaking. London: Cambridge University Press, pp. 92-109.

TOELKEN, B.

1979: The Dynamics of Folklore. Boston: Houghton Mifflin. YOUNG, E.R.

1893: Stories from Indian Wigwams and Northern Campfires. Toronto: William Briggs. 